\title{
Medical ethics: its current applications
}

\author{
Ratna Suprapti Samil
}

\begin{abstract}
Abstrak
Kode etik sebagaimana dipraktekkan dalam profesi kedokteran telah dikenal setidak-tidaknya sejak 2000 tahun lalu. Etika kedokteran yang mengatur hubungan antara dokter dan pasien mencakup tiga prinsip dasar, yakni autonomi, nilai dan kebajikan, serta keadilan. Etika merupakan suatu usaha untuk melakukan refleksi secara teratur tentang intuisi moral yang dilakukan oleh individu, sementara etika kedokteran dapat dipandang sebagai kewajiban berbasis moral yang mengatur praktek kedokteran. Dalam beberapa dekade terakhir telah terdapat kecenderungan yang meningkat untuk melihat etika kedokteran lebih penting dari masa sebelumnya. Keprihatinan masyarakat dewasa ini mengenai masalah etik telah mendorong profesi kedokteran untuk meningkatkan pemahaman pandangan masyarakat tentang masalah-masalah ini, dan situasi global sekarang ini memerlukan refleksi etik. Pada waktu yang sama, kemajuan ilmu dan teknologi, globalisasi ekonomi, dan perubahan-perubahan radikal dalam masyarakat membawa pertanyaan-pertanyaan moral yang tidak dapat dihindari. Meskipun terdapat tuntutan yang meningkat untuk memecahkan masalah-masalah etik secara lebih memadai, profesi kedokteran harus menghadapi sejumlah besar kasus yang masih tidak dibatasi dengan jelas. Beberapa masalah khas yang dihadapi para dokter termasuk alokasi pelayanan kesehatan, kewajiban dokter terhadap pasien, pelayanan medis baku atau prosedur baku, prosedur eksperimental dan inovatif, informed consent, malpraktek, dan kekeliruan dalam penilaian. Semua ini merupakan masalah yang akan selalu dihadapi dan dipecahkan oleh dokter.
\end{abstract}

\begin{abstract}
Ethical codes as practiced in the medical profession has been recognized since at least 2000 years ago. Medical ethics governing the relationship between physician and patient comprise three fundamental principles, i.e., autonomy, values and benevolence, and justice. Ethics in an attempt to undertake an orderly reflection on moral intuitions made by individual, while medical ethics may be considered as a moral based duty which governs medical practice. The last few decades have witnessed the increasing tendency of perceiving medical ethics as more important than ever. The current concern of society over ethical problems has led the medical profession to elevate its understanding of the society's views of these problems, and the current global situation calls for ethical reflection. At the same time, the advances of science and technology, economic globalization, and radical changes in the society raise moral questions which are unavoidable to us. Although there exist increasing demands for resolving ethical problems more adequately, medical profession must face a great number of still undefined cases. Several typical problems facing physicians include justice and allocation of health services, duties of the physician toward the patient, standard medical services or standard procedures, experimental and innovative procedures, informed consent, malpractice, and error in judgment. All these represent the problems that will be invariably faced and resolved by the physician.
\end{abstract}

Keywords: Ethics, values, medical ethics, ethical codes, medical profession, ethical problems

\section{INTRODUCTION}

The history of medical profession with the background of ethical codes dates back to at least $2000 \mathrm{BC}$. In the medical ethics formulated by Hammurabi, various ethical systems and rules concerning the practices of physicians have been established. There are several parts that concern noble moral norms and respon-

Honorary Council of Medical Ethics, Indonesian Medical Association

Department of Obstetrics and Gynecology, Faculty of Medicine, University of Indonesia, Jakarta, Indonesia sibility expected to be exercised by physicians which include guidelines to govern the relationship between physician and patient.

Medical ethics has 3 fundamental principles, i.e:

1. Autonomy

a. This principle requires the competence of people dictated by the autonomous wills and desires, and this competence is considered to be possessed by both the adolescent and the adult who have adequate understanding about each case in question, in addition to the abilities to bear the consequence of a decision independently made. 
b. Protection of the Weak

This principle signifies that we are demanded to provide necessary protection in caring for the children, adolescents, and adults who are in the unfavourable position and without autonomous competence. 1,2

\section{Virtue and Benevolence}

This principle is embodied in the medical ethics in a negative expression: Primum non nocere (Do not injure/harm). It would be advisable if we could express this meaning in a positive fashion: do good, and if necessary, we should initate the activities to promote the welfare of individuals and society.

\section{Justice}

This principle aims to promote justice in the transaction and actions between human beings, such as making effort to fullfill justice among the individual and society in which inappropriate risks and rewards exist, and to put into practice the principle that necessitates us to not sacrifice a group of human beings for the sake of other groups.

Currently, physicians may be involved in the practice hazardous to human beings. This sad history has led to the creation of the norms embodied in the Nuremberg Code which re-formulates medical ethics and other international codes, such as the Helsinki Declaration on the research on humans as a basis for bioethics. ${ }^{1}$

Ethics is an attempt to carry out an orderly reflection on the movement or moral intuitions that an individual makes. Medical ethics can be considered as a moralbased duty which governs medical practices. Over the last few decades, the problems of medical ethics remain more important than other problems in society with a concern focused on several main issues. The current society has been aggressively questioning the problem of how and to whom health-care services should be provided. The concern of society over ethical problems has led the medical profession to the increased demand of understanding the society's views, which not only are focused on the relationship between physician and patient, but also on the advances in science and technology of medicine affecting human rights, structure of society, and the policies of government in providing health services. ${ }^{3}$

Very often an ethical expert is expected to be able to resolve the problems of ethics faced. Such hope is intensified by a tendency to gain the ethical considerations from the expert on ethics. The assistance of an ethical expert provided through consultation can be seen in the field of engineering and finance. The expert of the latter field provide a concrete solution to the problems faced. In contrast, in the ethical field, an ethical decision must be made by the individual on his or her own. This duty cannot be delegated to other people. A British philosopher, C.B. Broad asserts that: "It is not part of the professional business of moral philosophers to tell people what they ought or ought not to do... Moral philosophers as such have no special information to the general public about what is right and what is wrong." 4,5

Decision made for an action and moral quality of the action lies with the individual himself. This problem becomes more acute in the medical profession, because the professional understands better the ethical implications of the problems faced and the efficient methods to deal with them. The ethicist can only help in preparing the making of the decision, or in evaluation of the decision made. In a concrete way, the assistance that can be provided by an ethicist may be summarized as follows: to analyze an ethical problem by bringing into light all the implications and explain the concepts pertaining to it. The problem itself and the concepts to be applied must be evident before we are able to consider a reasonable solution. For example, a discussion about euthanasia tends to be misleading because we are not clear enough about the notion signified by that term. Such is also the case with the discussion about intellectual property, human rights, social justice, and other actual topics. A conceptual analysis of the problem may shed light on the complexity of the problem and help us avoid a rush and lopsided solution. The current global situation requires an ethical reflection. The advances of science and technology, economic globalization, and radical changes in society, all these factors raise moral questions which are unavoidable to us.

It has been long emphasized that development is not confined to material aspects, but includes spiritual dimension. Ethics indisputably belongs to the latter area. The time and energy we devote to promoting ethics are not in vain, but will enhance the quality of our development. 4

\section{Justice and allocation in health services}

An employee in the field of health or a layman reading a newspaper or journal must be aware that the current health care is in unfavorable economic condition. The expenses rise exorbitantly to the extent that anyone not 
covered by health insurance or without pre-paid expenses, is almost impossible to be able to pay for a slight or routine medical intervention.

Part of the problem is attributed to the fact that the health system today is designed for providing quite expensive facilities of service which are businessoriented, such as other businesses which provide the tools and service which can hardly be afforded by the consumers. ${ }^{3}$

\section{Factors causing the ever-increased inflation in-} clude:

1. Many of the hospitals established are equipped with beds in a greater number than what is demanded to the extent that these hospitals must compensate for the unoccupied beds.

2. Medical practices become all the more sophisticated resulting in the creation of hospital business and the use of high technology.

3. The high technology available is not frequently used to the extent that facilities such CT-Scan, MRI, are utilized only by those who are in virtual need of them. The competition among the hospitals equipped with sophisticated equipment contributes to the increased rate of inflation.

4. The hospitals are required to provide expensive installations with the facilities that are only partially utilized such as emergency unit or Intensive Care Unit (ICU) which utilizes a great number of readily available paramedical personnel.

5. The physicians feel that they are entitled to ask for a high amount of reward as a compensation for their time-consuming and expensive education.

6. Technology in the routine health care, in addition to those who never take advantage of the equipment such as CT-Scan, demands an increasing amount of expenses.

7. Machine/equipment that can analyze 20 types of blood and chemical examinations is an extraordinary achievement, but must be expensively paid by the consumer.

8. A great number of tests and procedures undertaken are medically not accountable, and some are not considered necessary.

The increased use of malpractice has driven the physician to ask for more examinations/diagnosis that are considered to be true indications.
Good business must not be understood solely as the business that can create a large amount of profit. A good health-care service does not only mean a medical service that can be accepted in cost-benefit analysis. The good has a more fundamental meaning, i.e. a moral significance. The good in this sense constitutes the most fundamental dimension in human life. The good in a moral sense provides the most profound value for all the human activities. In ethics, we lay emphasis on this fundamental dimension. It is true that we do not have certainty in accomplishing tangible results, but we are sure that it is important to seek for something meaningful and accountable.

In the industrialized countries, funds for the current health-care system applied rapidly are not proportionate to the available sources, and therefore it is not always possible for the citizens to obtain the expected health-care.

It is evident that we must redress the imbalance between promotional, preventive, curative, rehabilitative and social service, and that we must make an evaluation of the benefit and loss of such an approach.

The acute problem in the medical field in this decade is due to the increased pressure from specialty of medicine that drives us to give priority to the sophisti-, cated and centralized facilities of health-care that has little relationship to the society's needs. We understand that the complex situation in science and technology has driven us to increased specialty and concentration in an ever-narrowing world. The positive impact of the above development is the marked development of science and technology and the ways the researchers broaden their discovery to be more profound.

The disadvantage is that the more we dig the more difficult it is to view our environment. As a result, the link of communication among different specialists in medicine becomes weak, the medical professionals are unable to look at their role in society holistically. Adding to this is the lack of recognition that the impact on community health exerted by curative medical practices is only a factor among numerous socioeconomic, political, and cultural factors. ${ }^{6}$

\section{INFORMED CONSENT}

Autonomy is a basic principle in medical ethics and it applies to both the patient and physician. Autonomy signifies a freedom to determine the future of each 
individual without being influenced by external pressures. Informed consent for treatment is one of the necessities that is not always applied by physicians throughout the history of medicine. This may be attributed to the paternalistic attitudes possessed by many physicians. Today, informed consent is an ethical necessity that must be completely accepted by the physician.

What does informed consent signify? According to the Committee of Human Rights established by the Ethical Committee of FIGO (International Federation of Gynaecology and Obstetrics), informed consent is an agreement obtained freely without any pressure or persuasion after the patient has obtained rational, clear and complete information communicated in a language easily understood by the patient.

Although the above definition is indisputably clear, the implementation of this principle frequently encounters difficulty and takes time to apply. This is perhaps conditioned by the unbalanced relationship among individuals in society that the independence in making a decision (self-determination) is easily violated. ${ }^{1,7}$

1. Human rights are easily threatened by socio-cultural and economic conditions. This occurs frequently because the relationship between physician and patient, particularly in the past, is characterized by a paternalistic nature.

2. Principle of autonomy plays an important role for the patients in making their decision in respect to their health-care. The physician must attempt to improve the easily-threatened situation due to the inability of the patient by securing their views and choices and respect them. ${ }^{8}$

\section{MALPRACTICE}

What is actually a malpractice? What is the duty of a physician toward his/her patient, or a standard medical service? And, what is the opinion of the physician about the patient? What is meant by a loss or harm? ${ }^{6}$

In an allegation made by the patient against the physician/health-care facility, the expression frequently used is "medical negligence", known as malpractice. This definition used for a malpractice is: an attitude that may cause a law prosecution as a consequence of the services provided professionally in medical/health field.

The terms who have similar meanings are: ${ }^{3}$

1. Negligence
2. Intentional misconduct

3. Breach of a contract guaranteeing a specific therapeutic result

4. Defamation

5. Divulgence

6. Unauthorized procedures

7. Failure to prevent injuries in certain non-patients

\section{SIMILARITY BETWEEN LAW AND MEDICINE}

There is striking similarity between law and medicine, i.e. if no allegations exist, all the matters should be previously proven. This principle is similarly expressed in formulating an appropriate diagnosis in medicine. For example, to establish a diagnosis of myocardial infarction, the patient must have all the specific symptoms and complaints, he/she must have an ECG and enhancement of ST, along with the changes in his/her enzymes.

However, there are a lot of undefined cases, and in such circumstances the principle that matters is the art and practice of medicine. In order to establish an appropriate diagnosis of myocardial infarction, we must have a number of acceptable reasons and explanations. If not, we will be driven to face the undefined cases. Note that a series of the acceptable criteria are necessary in determining the proper diagnosis, or in medical malpractice: A case should be reasonable and accountable. $^{3}$

\section{DUTIES OF PHYSICIANS}

The reasons for condemning a medical malpractice are easily understood. A physician has duties toward his/her patient. Normally, a duty begins to take effect once the physician and the patient enter into a voluntary interpersonal relationship. Once the physician has received a reward for the medical services he/she provides for the patient, an interpersonal contract is established. If the physician begins to provide treatment in the hope that he/she will be compensated, then an implied contract has been entered into, even though the service is provided with no charge. ${ }^{4}$

When and in what circumstances the relationship between the physician and the patient is established depends on the interpretation we make. This relationship could be initiated through the telephone communication to the physician's office or through a telephone answer, even though the physician has not seen the patient. 
Duties toward a non-patient could take effect on the basis of an agreement with a health-care facility in which the physician agrees to accept the telephone call. The duties are also possessed by a group of physicians as an instrument for the practice of the physicians group since each of the group member has shared responsibility in providing the treatment for the patient. Unless the patient has sought for treatment from another physician, or has terminated the relationship, or because of unusual circumstances which prevent the physician from carrying out his/her duties, the concerned physician exercises duties toward the patient. Nevertheless, in any case the physician is committed to carrying out the duties to make reasonable efforts until the patient has explicitly stated that he/she does not need the services provided. Normally, a physician cannot terminate his/her relationship with the patient until the patient has been informed about such a decision.

In certain circumstances, the physician is not free to terminate his/her relationship with the patient, even though such decision has been previously informed. This condition occurs when a specialist/surgeon agrees to perform a surgery even though he/she has decided to carry out the intervention. In this case, since the patient has placed his/her trust and planned to undergo the surgery, a breach in the contract may occur. However, this is not the case if the specialist/surgeon has decided to carry out the surgery, but because of unpredictable situations such as the fact that his/her colleague is more experienced and skillful, he/she then decides to arrange that the colleague performs such intervention. In such cases, the patient must be previously informed about the change of the surgeon.

If a physician terminates his/her relationship with the patient without previously informing his patient, it means that the physician has abandoned the patient. This is not the case if the physician has chosen his substitute (locum) because he/she must attend a scientific conference or take a vacation.

Each physician must specify the boundaries of his competence of practice. If, for example, the physician is employed at a clinic or health institution, the specific boundaries are normally specified within the area of the physician's practice. The physician must also carry out his tasks and duties toward the non-patients, such as the agreement with health insurance as a third party. ${ }^{4}$

\section{STANDARD MEDICAL SERVICE/STANDARD PROCEDURES}

If the physician is negligent and sued as a result of malpractice, this should be regarded as the case of violation of standard medical service. The negligence in the medical field is based on the state of the art and the advances of medicine during which the case occurs.

The status of physician as a professional working at a geographical area in which the case occurs also sets up the standard of the service. If a physician professes himself as a specialist in a certain field, he/she will be judged as a medical specialist in that field of competence regardless of his/her medical certificates. The majority of cases are assessed on the basis of standard service in the same location or compared with a similar case. In some cases, the standard service is specified as part of a peer review, or an assessment by the experts on the standard service used. Standards of quality assurance are normally set up by the institutions or government, such as the standards established by the Department of Health on diagnosis and treatment.

The physicians should not be blamed for adhering to the mode of treatment recognized by a number of his colleagues. The physicians cannot be prosecuted if they follow the method of treatment that has been recognized. This is of paramount importance because a problem faced by the patient may be resolved by several different methods. A physician cannot be blamed because the mode of treatment he adheres to results in unfavorable condition, unless the judge is able to prove that the physician has violated the standard medical services. ${ }^{2,8}$

\section{EXPERIMENTAL AND INNOVATIVE PROCE- DURES}

The physicians may be prosecuted if he is found to have undertaken an experimental medical intervention. In the case of innovative therapies, an informed consent must be previously secured from the patient, after he/she has been informed on the risks and benefits of this experimental, alternative treatment in which a research is the basis of that treatment. This will certainly be understood by the judge and the lawyers. ${ }^{3}$

\section{ERRORS IN JUDGEMENT}

If the physician carries out a series of standard medical services, he cannot be prosecuted for a mistaken diagnosis he has made or for the unfavorable therapy he performs. However, an error in diagnosis may be 
prosecuted or regarded as a negligence if the standard service is not fulfilled.

The unfavorable results occurs throughout the time, even though the physician has performed his/her medical science appropriately. A physician may be prosecuted for the unfavorable treatment he/she performs, but the prosecutor should be able to prove that the basic services provided have violated the established standards. ${ }^{3}$

\section{DAMAGES/HARM}

The incidence of malpractice is generally based on the treatment resulting in the damage/harm to the patient. In a law system this may assume the form of:

1. Failure in establishing a correct diagnosis, or making correct yet late diagnosis.

2. Incorrect administration of treatment or medications

3. Injuries made in an intervention of surgery

4. Failure in providing treatment, such as the administration of indicated medications or incorrect dosage of medications

5. Negligence in providing information about the plans for treatment

6. Failure in providing the explanation about the possible side effects or complications of the utilization of instruments or medical intervention

7. Failure in recognizing complications when they occur

8. Failure in recognizing the unfavorable effects of the facilities in the hospital which are used

9. Performing a medical intervention with inadequate facilities or with the inexperienced personnel serving as the assistant for the physician

The disadvantages may occur in any mode of treatment performed by the physician. A physician who serves as a laboratory head, or a consultant, or head of department may be prosecuted for a misleading report. ${ }^{3}$

\section{EXPERT WITNESS}

We should not be discouraged. Those who may prosecute a physician must invite an expert witness. The witness required is only a physician graduated from a medical school, and usually not a prominent physician competent in the specialty of the prosecuted physician, and usually he/she is a senior physician in whom the judges are trustful as he is the person who will be previously asked for explanation before the prosecuted physician. ${ }^{4}$

\section{WHY THE PATIENT PROSECUTES}

There are a great number of reasons why the patient initiates to prosecute a malpractice. ${ }^{3}$

1. Normally, the patient prosecutes because the results of the treatment do not measure up to his expectations, particularly when the relationship between the physician and patient is poor. When the patient is under the supervision of the physician, he loses his trust of the physician providing the treatment.

2. It could also be caused by an inadequate service or uncomfortable remarks made by a nurse, a physiotherapist, or a laboratory personnel to the patient which cause the patient to think that the physician has made his suffering more acute.

If the patient's expectations for the medical services provided by the physician are not fulfilled, he will ask whether the treatment provided for him is appropriate or not. Usually, the patient will consult his friend or family, and finally he is advised to bring his case to court, because he thinks then that he has been mistreated by the physician, and cases like this will increase in society.

\section{CONCLUSIONS}

\section{Allocations}

Resources for health services is increasingly diminishing, and becoming more expensive, while our population will continue to grow, and so will the inflation. From the economic, ethical and political perspectives, the above tendencies will result in contradictions. Each of the above aspects has shown its decreasing tendency. For example: educated and trained technicians, organs for transplantation, research facilities, and funds.

The problem we are facing is how to distribute the resources equally to those in need of them. In the ethical field, this problem is a justice problem; how to ensure that each person requiring health services may obtain it fairly. In the political field, the problem is what are the efforts we should make so that each individual feels content and happy in a situation filled with numerous problems. 
Allocations can be divided into 2 types:

\section{Macro allocation:}

What is the amount of fund needed to be prepared by the society for obtaining health services in comparison with other necessities such as education and defence.

\section{Micro allocation:}

Micro allocation corresponds to the necessities of the health personnel or each health facility/institution in undertaking its functions.

Therefore, currently the system of health service has changed into the transaction market with increasing cost, but decreasing administrative efficiency. Several factors causing inflation are related to the personal aggrandizement and the deteriorating management. As a result, the distribution is not equally and fairly provided, particularly for the poor. The allocation of resources determines the quality of services and the number of services, and what can be provided for a group of people. Since not all the people can be provided with the services by the existing system of health, a justice must be realized in the allocation of the available resources. ${ }^{4,5}$

The fundamentals of justice are not required by those who have been fair and just and are dictated by the principle of common collaboration. The right for health services has been debated in the context of right and justice. Since the right also implies the duty, the right for health services must be accompanied by the attitudes of the individuals supporting the protection and promotion of their personal health. ${ }^{7}$

\section{REFERENCES}

1. Samil RS. Current application of medical ethics. 48th Dies Natalis of the University of Indonesia, Faculty of Medicine, Jakarta, 1997 (in Indonesian).

2. Samil RS. Ethical aspects in handling victims of violence. Workshop on Medical Aspects of Violence Victims. Jakarta, 1996 (in Indonesian).

3. Margot JF. Ethical issues in health care. St. Louis: Mosby; 1981:54-9.

4. Evans D, Evans M. A decent proposal, ethical review of clinical research. Chicester: Wiley \& Sons: 1996:78-82.

5. Bertens K. Applied ethics: new challenges in an old traditin Professorial Inaugural Speech. Atma Jaya Catholic University, Jakarta, 1995 (in Indonesian).

6. Thom E, Lobe MD. Medical malpractice. New York: McGraw-Hill; 1995:209-13.

7. Samil RS. Medical ethics. Jakarta: Balai Penerbit FKUI, 1994 (in Indonesian).

8. Samil RS. Preparing obstetricians and gynecologists towards the era of globalization. Oration at the 10th Congress of Indonesian Obstetrics and Gynecology. Padang, 1996 (in Indonesian). 